https://helda.helsinki.fi

\title{
An analysis of travel reports of the Finnish botanical expeditions to Russian Lapland (Murmansk Region and northern Karelia) in 1861 and 1863
}

Kozhin, Mikhail N.

2020-10

Kozhin , M N \& Sennikov , A N 2020 , ' An analysis of travel reports of the Finnish botanical expeditions to Russian Lapland (Murmansk Region and northern Karelia) in 1861 and 1863 ' , Nordic Journal of Botany , vol. 38 , no. 10 , 02795 . https://doi.org/10.1111/njb.02795

http://hdl.handle.net/10138/335616

https://doi.org/10.1111/njb.02795

acceptedVersion

Downloaded from Helda, University of Helsinki institutional repository.

This is an electronic reprint of the original article.

This reprint may differ from the original in pagination and typographic detail.

Please cite the original version. 
1 An analysis of travel reports of the Finnish botanical expeditions to Russian Lapland (Murmansk Region and northern

2 Karelia) in 1861 and 1863 
(Abstract)

4 Finnish botanical expeditions, which were made to Russian Lapland (present-day Murmansk Region and northern

5 Karelia, Russia) in 1861 and 1863, published travel reports with preliminary information, which contained numerous

6 floristic novelties and phytogeographical observations but have been overlooked in present-day studies. Two reports

7 appeared in print, by Gustav Selin on the expedition made in 1861, and by Nils Isak Fellman on the expedition made in

8 1863. We analysed mentions of vascular plant species published in these travel reports in order to trace and evaluate first

9 records and localities of rare and legally protected species on the basis of herbarium vouchers kept at $\mathrm{H}$. In spite of high

10 self-claims, Selin actually reported 9 species new to present-day Murmansk Region and 1 species new to Republic of

11 Karelia, and 4 species of vascular plants that are currently under legal protection in Murmansk Region, whereas Fellman

12 reported 11 species new to Murmansk Region and 5 species new to Karelia, with 34 species under legal protection in

13 Murmansk Region. First records of alien plants were 7 species from Selin and 4 species from Fellman. These numbers

14 brought the contemporary floristic knowledge in Russian Lapland to 504 species of native plants (50\% of the current

15 total) and 54 species of alien plants ( $11 \%$ of the current total). Fellman's report included the first phytogeographical

16 observations from the Kola Peninsula, with the first botanical limits observed, and the first descriptions of key botanical

17 territories which are currently under strict protection. This study contributes to botanical history, plant protection and

18 management of plant invasions in Murmansk Region. 


\section{Introduction}

Lapland is a historical territory in Fennoscandia lying largely north of the Arctic Circle. This territory received its name from the Sámi people, a Fenno-Ugric nation called Lapps in previous times, who are indigenous to the area. It has never been officially defined, and its limits varied with changes in scientific concepts and delimitation of northern administrative territories (present-day or historical) of the Nordic countries (Finnmark in Norway, Lapland in Sweden, Lappi in Finland). Whereas the western part of Lapland (Sweden and Norway before 1809) had received much attention of botanists already in the $18^{\text {th }}$ and early $19^{\text {th }}$ centuries (Linnaeus 1737, Wahlenberg 1812), the western part (Russia) was a true terra incognita with no features of flora and vegetation known (Sennikov and Kozhin 2018).

The first checklist of vascular plants of Russian Lapland (present-day Murmansk Region and the northern part of Karelia, Russia) was compiled by Jacob Fellman, who was a priest at Utsjoki, northern Finland (Väre 2011). The checklist (Fellman 1831) was based on Fellman's own herbarium collections, which eventually were acquired to H but not before 1920 (Väre 2011).

Fellman's checklist remained the only source of information on the flora of Russian Lapland in the first part of the $19^{\text {th }}$ century, in spite of the efforts of some scientists employed by the Russian Academy of Sciences; the results of those travels and collecting activities remained unpublished and inaccessible except for a few brief reports in academic periodicals (Sennikov and Kozhin 2018).

When the Societas pro Fauna et Flora Fennica (further referred to as the Society) published its first checklist (Nylander and Sælan 1859) of the flora of East Fennoscandia (Finland and neighbouring Russia), which was strictly based on the herbarium collections accumulated by the Society, the shortage or even lack of collections from Russian Lapland became apparent. This was especially true when the new checklist and analysis of the flora of Western Lapland was published (Andersson 1846). In late 1850s and early 1860s, the Society became a very strong scientific organization, leading the studies of natural history in Finland; with its own funds and the availability of financial support from the University of Helsinki and associated foundations, the Society decided to organise expeditions to little known areas of Finnish interest in order to fill the gaps in knowledge and collections (Wallgren 1996).

Two big expeditions to the north-east, which aimed to collect insects, plants, lichens and fungi of the Kola Peninsula, were organised and took place in 1861 and 1863 (Sennikov and Kozhin 2018). These expeditions are linked with the name of Nils Isak Fellman (1841-1919), then a 20-years-old student of the University of Helsinki. In 1861, two groups were directed to explore various parts of the Peninsula. The first group (N.I.Fellman, P.A.Karsten) covered the 
western part, whereas the second group (G.Selin, K.E.Inberg) was supposed to travel along the coasts of the White Sea and then the Barents Sea westwards to the main road from Kola but cancelled the original plan and explored only the western part of the Peninsula. In 1863, a single team (N.I.Fellman, who became the leader because of his experience and age, M.M.W.Brenner, N.J.Laurin) travelled extensively around the whole Kola Peninsula and returned back along the main road (Kola - Kandalaksha).

The expeditions intended to cover gaps in the knowledge of various groups of vascular plants and cryptogams in Russian Lapland. The other purpose was to collect herbarium specimens for the Museum of Natural History, University of Helsinki, which was de facto managed by the Society (Wallgren 1996); the curatorial idea was to have a complete representation of the flora in collections, with at least one specimen per species from each biogeographic province (Nylander and Sælan 1859). The materials collected by these expeditions were abundant and brought a wealth of scientific information, published as regional monographs on lichens (Nylander 1866), fungi (Karsten 1866), and vascular plants (Fellman 1869).

Since at that time the Kola Peninsula was among the least known territories in Europe, the results of this expedition were much appreciated and laudably accepted in Europe. Prior to their full-size publication, selected discoveries in vascular plants and general features of the vegetation were described in a letter sent by Fellman in September 1863 on the way back from Kola to Helsinki to the president of the Society, William Nylander, who at that time resided in Paris. Nylander read Fellman's travel report on 27 November 1863 at the meeting of the French Botanical Society, which was published in French in the journal of that society (Fellman 1864a) and quickly translated into German (Fellman 1864b) and English (Fellman 1865). The Russian translation was published recently (Sennikov and Kozhin 2018).

Another letter was sent to Nylander on 5 August 1862 by Gustav Selin, reporting the summary of his main botanical discoveries in 1861. In Autumn of 1862, after Selin's death, this report was approved for publication by the Society but was not published in time because of the lack of means of rapid publication in Finland; ultimately, it was published as Selin (1869), and its Russian and English translations appeared in Sennikov and Kozhin (2018).

Despite the considerable fame achieved by the Finnish expeditions to Russian Lapland in 1861 and 1863, there is a certain level of obscurity which hindered details of their travels and collecting activities. The brevity or absence of precise data (or erroneously stated data) on distributed specimens and in original publications resulted in a common confusion between the two expeditions, and in a mess with their collecting localities and their locations. These technical 
101

102

103

particulars were clarified in Sennikov and Kozhin (2018) but an analysis of botanical activities of the expeditions remains to be produced and published.

The publications of these expeditions were much appreciated and laudably reviewed, and had a great impact on further botanical studies in Russian Lapland. However, they have not been evaluated for the level of novelty and accuracy in their floristic inventory, and the value of preprinted information (travel accounts) has been forgotten.

This contribution is part of a larger study dedicated to the botanical legacy of Nils Isak Fellman (Sennikov and Kozhin 2018). The early botanical outputs of Finnish botanical expeditions to Russian Lapland are the subject of the present contribution, with the aims to analyse all mentions of vascular plants which were published in Fellman's and Selin's travel reports and represent the first records of rare and protected species of vascular plants in Murmansk Region. These records have been very incompletely taken into account in the Russian literature (Gorodkov 1953-1954, Pojarkova 1956-1966), and their background documentation has never been analysed and verified. We also place the expeditions in the context of botanical studies in Russian Lapland in the $19^{\text {th }}$ century.

\section{Materials and methods}

\section{Published sources}

Two published sources, travel reports of Fellman (1864a) and Selin (1869), were screened and analysed for records of vascular plant species from Murmansk Region and neighbouring Karelia, which were the first reports of scientific results of the Finnish botanical expeditions to Russian Lapland in 1861 and 1863 (Sennikov and Kozhin 2018). Among the four versions of Fellman's report (Fellman 1864a, 1864b, 1865, Sennikov and Kozhin 2018), the original (French) version was used.

The obtained records were checked for floristic novelties against contemporary checklists and accounts (Fellman 1831, Ledebour 1841-1853, Nylander 1843, 1844, 1846, Nylander and Sælan 1859).

\section{Study area}

Since 1850s, the studies of natural history in East Fennoscandia were based on the scheme of biogeographic provinces produced by members of the Society (Wallgren 1996). The Finnish botanical expeditions studied the 
biogeographic province Lapponia rossica (Russian Lapland), which at the time was defined to include territories north

107 of the Kem River and Lakes Kuittijärvet (now in Karelian Republic, Russia) until the Barents Sea shore, i.e. the whole

108

109 of Murmansk Region of Russia (Nylander and Sælan 1859). The southern border of Russian Lapland was the northern limit of Karelia rossica (Russian Karelia). Later (Sælan et al. 1889) the biogeographic border between Lapland and Karelia was redefined and moved northwards to the Kanda River (now in Murmansk Region); the southern part of the former Lapponia rossica became part of the biogeographic Karelia as Karelia keretina.

In the present contribution, we are focusing on localities visited and sampled by the expeditions strictly within Lapponia rossica as defined in Nylander and Sælan (1859). Most of this territory falls into present-day Murmansk Region of Russia but a minor part belongs to the Republic of Karelia of Russia (Fig. 1). Published records and herbarium specimens from other territories, referable to Karelia rossica as defined in Nylander and Sælan (1859), are not included in the present study.

\section{Herbarium materials and species records}

The herbarium collections of vascular plants, obtained in the course of the expeditions, had been completely deposited in the Botanical Museum (now Finnish Museum of Natural History), University of Helsinki (H). These collections were traced, recorded and submitted to the Finnish Biodiversity Information Facility (https://laji.fi/), the online database accumulating floristic records of the University of Helsinki, and to the database of the project 'Flora of Russian Lapland' (www.laplandflora.ru, now at test stage) which is maintained at the Moscow State University. Localities and dates given on labels of herbarium specimens were checked and complemented using the routes of the expeditions (Sennikov and Kozhin 2018). Taxonomic literature and floristic treatments were used to clarify the taxonomy and identity of herbarium specimens. Identifications in herbarium collections were checked, updated and corrected, and used in verification of the background of the published records. In our identifications, all recent taxonomic treatments were critically assessed and taken into account by the authors. Species distributions in Murmansk Region were verified using standard reference books (Gorodkov 1953-1954, Pojarkova 1956-1966, Hultén 1971, Ramenskaya and Andreeva 1982, Konstantinova et al. 2014).

Plant records traced from Fellman (1864a) and Selin (1869) are collected in Appendices 1 and 2, in which the data on nomenclature, current taxonomy, background information (herbarium vouchers), and accepted taxonomic identity are provided for each record. The status of each record was assessed and is indicated as follows: novelty to the 
135 province Lapponia rossica according to Herbarium Musei Fennici (Nylander and Sælan 1859), that means presence or

136 absence of relevant specimens in the collections of the Society; novelty to Lapponia rossica according to the published

137 information (Fellman 1831, Ledebour 1841-1853, Nylander 1843, 1844, 1846, Nylander and Sælan 1859), that means

138 the first published record from the territory; novelty to Murmansk Region and Karelia (present-day administrative

139 territories of Russia), that means our assessment of the background material (taxonomic acceptance and territorial

140 assignment).

$141 \quad$ Native and non-native plants are analysed separately because of their contrast history in the local flora. A species

142 is considered native if arrived to the territory in pre-historical times, presumably without human assistance. Non-native

143 plants include both neophytes (arrived after 1492) and archeophytes (arrived before 1492); species included in these

144 categories appeared in the territory with direct or indirect assistance of humans, irrespective of their times of arrival and 145 their level of naturalisation.

146

147

148

151

152

153

154

155

156

157

158

159

160

161

162

163

\section{Results}

The Finnish botanical expeditions to Russian Lapland in 1861 and 1863 had two goals, to collect specimens for the Herbarium Musei fennicae, and to improve the botanical knowledge and produce a new checklist of the regional flora. The checklist Herbarium Musei fennicae (Nylander and Sælan 1859) was strictly based on the herbarium collections at $\mathrm{H}$; more correctly, it was not a floristic checklist but a curatorial herbarium inventory that served as a checklist and at the same time as a desideratum calling for further collecting activities. This checklist omitted published information if the specimens were not deposited at $\mathrm{H}$; for this reason, about $40 \%$ of records published in Fellman (1831) and Ledebour (1841-1853) were not included in Nylander and Sælan (1859) because the relevant specimens were kept in the private collections of these authors or at LE (Fig. 2). As a result, the novelties reported by the Finnish expeditions were rather novelties to the Finnish collections than to the available knowledge, and should be evaluated as such.

To show the rapid progress and the success of the expeditions, Fellman, Karsten and Selin reported the number of new species to the Society, based on specimens collected in 1861. Regarding vascular plants, with Herbarium Musei fennicae as a guide, Selin reportedly collected 237 species new to Karelia rossica and 125 species new to Lapponia rossica, of which two species were new to East Fennoscandia (Helsingfors Dagblad, № 285, p. 1, 8 December 1862), whereas Fellman reported 155 species new to Lapponia rossica, of which one species (Sparganium hyperboreum Laest. ex Beurl.) was new to East Fennoscandia (Helsingfors Dagblad, № 54, p. 1, 6 March 1863). Since these impressive 
numbers denoted novelties to the collections, the actual increase of floristic knowledge cannot be inferred from this information.

\section{Travel report of Gustav Selin, dated 1862, published in 1869}

\section{$\underline{\text { Floristic novelties }}$}

The travel report of Gustav Selin (1869) was based on his expedition to the Kola Peninsula made in 1861. For technical reasons, on the way to Lapland Selin spent extra time in Russian Karelia, and his collections from the target area were not as rich as expected (Sennikov and Kozhin 2018). Nevertheless, he claimed to have collected 125 species of vascular plants new to Lapponia rossica, including two species new to East Fennoscandia, of which one species ('Potentilla nivea' L.; correct identification: Potentilla chamissonis Hultén) was collected in the Khibiny Mts. in Russian Lapland.

In the report Selin explained that he assumed his major task as filling the gaps in the collections; for this reason, he collected and reported many rather trivial plants typical of forests, meadows and paludified areas, which were formally missing in the collections from his study area. For this reason he recorded only 4 species of vascular plants that are currently under legal protection in Murmansk Region (Konstantinova et al. 2014).

Among the vascular plants collected and mentioned by Selin (1869), we verified on the basis of Selin's specimens and contemporary literature that 10 species had never been reported from Lapponia rossica in published sources, including 9 species new to present-day Murmansk Region and 1 species new to Karelia. Among the species previously reported as presumably present in Russian Lapland, Sagina nodosa (L.) Fenzl was actually reported first by Selin because Fellman (1831) included this species in his list of Kola plants on the basis of material collected in Varanger Fjord (now part of Norway), and Ledebour (1842) mentioned 'Kola' on the basis of Fellman's record only.

\section{Non-native species}

Selin made no significant phytogeographical observations in his travel report. This may be another reason why his expedition was not considered successful (Sennikov and Kozhin 2018). However, Selin collected the species which had not been appreciated in his times but are in focus of active studies nowadays, i.e. non-native plants. 
In his report, Selin included 7 alien plants new to present-day Murmansk Region. Those plants were collected in

194 Russian fishermen's villages along the Kandalaksha and Tersky coasts of the White Sea. Notably, he collected Galium

195

196

197

198

199

202

\section{mollugo L., Pimpinella saxifraga L., 'Hypericum quadrangulum L.' (= H. maculatum Crantz), and Linaria vulgaris}

Mill. in Umba Village; these plants still occur on anthropogenic (managed for hay-making) meadows in the old part of the village (Kozhin, pers. obs. 2010-2019).

Along the Kandalaksha Bay, Selin observed Urtica urens L., which was known from 5 localities in the beginning of the $19^{\text {th }}$ century (Fellman 1831) and from 11 localities in the end of the $19^{\text {th }}$ century (Hjelt 1902). To the present day, the number of localities and abundance of this species have considerably decreased.

Altogether, Selin's work had increased the knowledge of the alien plant diversity in Russian Lapland by 15\%.

\section{$\underline{\text { Unreliable record }}$}

Among other records, Selin (1869) reported Hieracium saxifragum Fr. from the Kildin Island. No relevant specimen has been traced in the collections. So far, this record is considered doubtful because the only species of Hieracium sect. Oreadea Fr. in the Russian north is known from Liinahamari at the border with Norway, far from Kildin (Schljakov 1966).

\section{Travel report of Nils Isak Fellman, dated 1863, published in 1864}

\section{$\underline{\text { Floristic novelties }}$}

The travel report of Fellman (1864a) mentions a number of remarkable and characteristic plant species of Russian Lapland, based on the results of the expeditions in 1861 and 1863. After 1861, Fellman's expedition reported that 155 species were collected as new to Lapponia rossica; in 1863, Fellman was more concentrated on rare species and features of plant geography.

We have evaluated the records published in Fellman (1864a) for taxonomic accuracy and floristic novelty. The resulting statistics are summarised in Table 1, counting novelties according to historical biogeographic provinces and present-day administrative territories, separately for each expedition and each team on the basis of the background herbarium data. 

Fennici (Nylander and Sælan 1859), of which some may be considered rare (Poa caesia Sm., Eriophorum callitrix Cham. ex C.A.Mey. (correct identification: E. brachyantherum Trautv. \& C.A.Mey.), Luzula hyperborea R.Br. (= L. confusa Lindeb.), Gentiana tenella Rottb. (= Comastoma tenellum (Rottb.) Toyok.), Astragalus oroboides Hornem. (= A. norvegicus Weber), Paeonia anomala L., Cochlearia officinalis L., Gypsophila fastigiata L.) but the others are contemporary literature (Fellman 1831, Nylander 1843, 1844, 1846, Ledebour 1841-1853). Only 15 species were new to Lapponia rossica, of which 11 species were new to Murmansk Region and 5 species were new to Republic of Karelia. For example, although Fellman (1864a) specifically reported Subularia aquatica L. as a novelty to Russian Lapland, it was actually published earlier, both from Murmansk Region (Fellman 1831, Ledebour 1842) and Republic of Karelia (Nylander 1852, Nylander and Sælan 1859).

Fellman's expedition of 1863 concentrated on the least studied territories of the eastern part of the Tersky Coast of the White Sea and the East Murman Coast of the Barents Sea. In 1863, 52 species were collected as new to Russian Lapland were 29 species, of which 7 species were also collected in 1861. New to Murmansk Region were 25 species, of which only 4 species were recollected. This higher level of novelty may be explained by the formerly poor knowledge and unique features of the flora of the eastern part of the Kola Peninsula, which was intensely sampled by Fellman. Among 8 species new to East Fennoscandia, which were previously absent in Herbarium Musei Fennici, 6 species were collected in the east, in the area of the Ponoi River.

It is worth noting that Fellman (1864a), as compared with the latest Red Data Book of Murmansk Region (Konstantinova et al. 2014), reported 34 species of vascular plants that are under legal protection in Murmansk Region. So high level of botanical information relevant for plant protection was possible only because Fellman was concentrated on rare plants in his study.

Altogether, based on the work of his teams in 1861 and 1863, Fellman (1864a) reported 37 species as new to Russian Lapland, which constituted an addition of $8 \%$ to the previously known plant diversity of this territory. Summarizing the data from all published sources including Fellman (1864a), now we know that there were 504 species 
of vascular plants recorded by 1864 in the flora of Russian Lapland, with 450 native species which make $50 \%$ of the

252 currently known native flora of Murmansk Region (Kozhin and Sennikov 2019).

253

254

255

\section{Phytogeographical limits}

Besides reporting the most important (rare or otherwise special) plants, Fellman (1864a) mentioned a number of more common plants characteristic of certain territories and landscapes. This was done in a phytogeographical context: Fellman attempted to give a botanical description of major biomes in the Kola Peninsula and to trace the patterns of their distribution and their limits.

The territory best studied by Fellman was the southern and eastern coasts of the Kola Peninsula, i.e. the coasts of the White Sea. He noticed two limits connected with major changes in landscapes and plant communities. The first limit he has drawn at the Turii Mys cape; the coast is rocky and composed of granite outcrops west of this point, whereas it turns low and sandy east of this point. The second limit Fellman had found in the vicinities of Pyalitsa Village; east of this point he observed more raised coasts with rocky and clayey places.

To characterise the territories delimited by these points, Fellman used the data on the coastal relief, bedrocks and soils, and also the limits of forest and particular trees. Along the southern coast of the Peninsula he observed spruce, birch and pine as main forest trees. He demonstrated a regular decrease in forestation and abundance of all particular tree species in the west-east direction. The most drastic decrease he noticed in pine, which retreats towards inland in the eastern part of the Peninsula. As described by Fellman, the western part of the White Sea Coast is completely forested, whereas in the east, starting from Pyalitsa, the coast is devoid of trees and only in a few kilometres inland one can find sparse forests of mountain birch with contorted trunks. Nevertheless, Fellman concluded that trees can be found in depressions of any territories in Russian Lapland, from the Rybachii Peninsula in the extreme west to the Ponoi River in the extreme east.

Besides describing changes in tree species, Fellman gave a brief characteristic of plant communities and their distribution. He termed the plant cover of the eastern coast of the Kola Peninsula (between Pyalitsa Village and Ponoi River) as "tundra" and subdivided it further into "dry tundra" and "moist tundra". Based on Fellman's descriptions and mentions of characteristic plant species, we interpret this terminology in the following way. "Dry tundra" is tundra in present-day meaning of this term; Fellman characterised it by Cladonia sp., Stereocaulon sp., Platysma nivale (L.) Frege (= Flavocetraria nivalis (L.) Kärnefelt \& A.Thell), Empetrum nigrum L. s.1., Arctostaphylos alpina (L.) Spreng. (= 
Arctous alpina (L.) Nied.), Calamagrostis neglecta Gaertn., B.Mey. \& Scherb. (= C. stricta (Timm) Koeler), Festuca sp. etc. His "moist tundra" seems to correspond to mires with the following characteristic species: 'Carex ampullacea Gooden.' (= C. rostrata Stokes), Eriophorum angustifolium Honck., E. vaginatum L., 'E. alpinum L.' (= Trichophorum alpinum (L.) Pers.) etc.

In spite of the brief format of scientific communication, Fellman (1864a) provided the first scientific data on the plant geography of the Kola Peninsula. These observations, further elaborated in Fellman (1869), became the basis for the more detailed biogeographic division of Russian Lapland (Hjelt 1888, Sælan et al. 1889, Bomansson and Brotherus 1894, Anonymous 1938). The biogeographic limits drawn by Fellman correspond to the borders between Lapponia Imandrae and Lapponia Varsugae (Turii Mys), and between Lapponia Varsugae and Lapponia ponojensis (Pyalitsa Village) (Fig. 3).

\section{Distribution patterns of tree species}

Fellman (1864a) paid particular attention to the diversity and distribution of forest trees in the Kola Peninsula. Among the most important timber trees of the region, he detailed the taxonomy of spruce, formerly passed under the collective name Pinus abies L. and absent from the Finnish collections of the region (Nylander and Sælan 1859). Fellman reported the occurrence of three distinct taxa of spruce in Russian Lapland, with different geographical distributions. He observed the typical 'Pinus Abies' (= Picea abies (L.) H.Karst. subsp. abies; current taxonomy of spruce after Kurtto et al. (2019)) only west of Kandalaksha, whereas 'Pinus abies var. medioxima' (Picea abies subsp. $\times$ fennica (Regel) Parfenov) and 'Pinus obovata' (= Picea abies subsp. obovata (Ledeb.) Domin) were found as common in East Lapland.

Birch is as important as spruce in forests of Russian Lapland. Fellman (1864a) specified that 'Betula alba' is a common tree in the inner part of the Kola Peninsula; at present, these plants have been referred to B. pubescens Ehrh. subsp. pubescens in the south-western part of Russian Lapland and to B. pubescens subsp. subarctica (N.I.Orlova) Á.Löve \& D.Löve in its central and eastern parts. He mentioned the occurrence of another taxon, 'B. tortuosa' in the coastal area of the Peninsula, which is a mixture of $B$. pubescens subsp. czerepanovii (N.I.Orlova) Hämet-Ahti and $B$. ×alpestris Fr. (Hämet-Ahti 1987, Tzvelev 2004).

Fellman (1864a) was also first to demonstrate the differences between the alder of the Kola Peninsula, which he referred to 'Alnus pubescens', and the common alder A. incana (L.) Moench. The Kola alder has rather obtuse green 
leaves (vs. acute to subacute grey leaves) and has been recently described as A. kolaënsis N.I.Orlova (=A. incana subsp. kolaensis (N.I.Orlova) Á.Löve \& D.Löve); it is highly similar to the recent hybrid between A. glutinosa (L.) Gaertn. and A. incana and may have originated as a stabilised hybridogenous taxon of the same origin (Tzvelev 2004). Fellman (1864a) observed that alder is widespread in Russian Lapland but disappears north of the Ponoi River.

Among the other arboreous species, Fellman (1864a) reported Sorbus aucuparia as widespread in the Kola Peninsula, going as far north as to Kildin Island. He also observed Cotoneaster integerrimus Medikus s.l. (as ' $C$. vulgaris') along the White Sea coast up to the Ponoi River. Both observations are still in match with the modern data (Kurtto et al. 2013).

\section{Comparisons of the flora of coastal areas}

Since the expeditions in 1861 and 1863 largely followed the sea coasts, Fellman (1864a) observed and described peculiarities of the flora of the White Sea and the Barents Sea coasts.

Fellman provided rather extensive lists of characteristic plants of the sea shores. Along the Barents Sea, he observed a number of plants typical of tundra, namely Poa pratensis var. alpigena Fr. ex Blytt (= Poa pratensis subsp. alpigena (Fr. ex Blytt) Hiitonen), Catabrosa latifolia (R.Br.) Fr. (= Arctagrostis latifolia (R.Br.) Griseb.), Carex rigida Good. (= C. bigelowii Torr. ex Schwein.), Hieracium alpinum L., Luzula hyperborea (= L. confusa), Silene acaulis L., Ranunculus pygmaeus Wahlenb., Diapensia lapponica L. Along the White Sea, many boreal species were observed, namely Luzula pilosa (L.) Willd., Maianthemum bifolium (L.) F.W.Schmidt, Lonicera coerulea L., Orobus vernus L. (Lathyrus vernus (L.) Bernh.), 'Actaea spicata [f.] erythrocarpa Turcz.' (= A. erythrocarpa (Fisch. \& C.A.Mey.) Mørch) etc. Present-day knowledge classifies these coasts in different ecosystems: the Barents Sea coast was referred to south tundra (Alexandrova 1977), forest tundra (Safronova et al. 1999) or northern boreal zone (Ahti et al. 1968), whereas the White Sea coast was referred to northern boreal zone (Ahti et al. 1968), corresponding to northern taiga of Russian authors (Safronova et al. 1999).

Fellman listed rather many sea shore species which are obligate or facultative halophytes. Quite a number of such species he mentioned from the Barents Sea coast, although these species also occur along the White Sea coast: Matricaria inodora var. phaeocephala Rupr. (Tripleurospermum maritimum subsp. subpolare (Pobed.) Hämet-Ahti, Calamagrostis stricta, Elymus arenarius L. (= Leymus arenarius (L.) Hochst.), Rhodiola rosea L., Lathyrus maritimus (L.) Bigelow, Stellaria crassifolia Ehrh., S. humifusa Rottb., 'Selinum tataricum (Fisch.)' (= Conioselinum tataricum 
Hoffm.), Haloscias scothicum (L.) Fr. (= Ligusticum scothicum L.). As a species peculiar to the White Sea coast Fellman reported Ranunculus polyanthemos L. as well as Zostera marina L.; the latter was characterised as common along the western coast of the White Sea. Fellman noted large heaps of Zostera thrown on shore by the sea; this fact was not known to Vekhov (1992) who studied mass death of Zostera as a new phenomenon in the $20^{\text {th }}$ century.

\section{$\underline{\text { Botanically important territories and new records }}$}

The Finnish botanical expeditions in 1861 and 1863 had visited some botanically important places of Russian Lapland. The most important territory highlighted by Fellman (1864a) was the lower course of the Ponoi River, which he praised as the territory 'from which our best collections had originated'. Fellman gave a brief characteristic of the vegetation of this river valley. He mentioned Androsace septentrionalis L., Asplenium crenatum Fr. (= Diplazium sibiricum (Turcz. ex Kunze) Sa.Kurata), Armeria arctica (Cham.) Wallr. (= A. maritima subsp. sibirica (Turcz. ex Boiss.) Nyman), 'Eriophorum callitrix' (correct identification: E. brachyantherum), Eutrema edwardsii R.Br., Gentiana tenella (= Comastoma tenellum), Paeonia anomala, Ligularia sibirica $($ L.) Cass., Hedysarum arcticum B.Fedtsch. $(=H$. obscurum L.), Gentiana nivalis L., 'Aconitum lycoctonum' (correct identification: A. septentrionale Koelle); the data on legally protected species from this list have been lately taken into account in the Red Data Book of Murmansk Region (Konstantinova et al. 2014). Some rare species found by Fellman ('Poa sudetica var. remota (Forselles) Fr.' = P. remota Forselles, Pedicularis sudetica Willd.) are known only in the south-eastern part of the Kola Peninsula. In the latest decades many other rare species have been found in the Ponoi area. For this reason, G.N. Andreev, M.L. Ranemskaya and R.N. Schljakov in 1972 elaborated a proposal to establish a new protected area named "Rare plant species in the lower course of the Ponoi River" (Kryuchkov et al. 1988), but this idea has never been implemented. In 2002, river sides in the lower course of the Ponoi River were included in the Ponoi Fish Sanctuary, which aims at preservation of natural landscapes for sustainable use of natural resources. In 2018, on the basis of new field data, we proposed to establish a new botanical protected area (sanctuary) at the regional level of protection (Belkina et al. 2018, Kozhin et al. 2018).

The expeditions have also visited and specially noted the Turii Mys cape, which is one of the most famous protected areas in the Kola Peninsula. In this place they have found Androsace septentrionalis, 'Hedysarum obscurum' (correct identification: H. alpinum L.), Helianthemum vulgare Gaertn. (= H. nummularium (L.) Mill.). The record of Helianthemum was most remarkable at that time because the nearest localities of that species are situated about $1000 \mathrm{~km}$ 
southwards (Tzvelev 1996). Based on Fellman's collections, this population was described as a local endemic, $H$. arcticum (Grosser) Janch. (Grosser 1903, Janchen 1909, Tzvelev 1996), which has been legally protected at the national level (Filippova 1988, Kostina 2008) as endangered. Lately the taxonomical status of H. arcticum was reconsidered; on the basis of phylogeographic analysis, Volkova et al. (2016) concluded that this taxon represents an outlying peripheral population of $H$. nummularium which was preserved since the last postglacial major range expansion of this species, and bears the same plastid haplotype as the bulk of east and north European populations.

After Fellman, in the $19^{\text {th }}$ and $20^{\text {th }}$ centuries Turii Mys was frequently visited by botanists who discovered numerous populations of rare plants and spruce forest of the middle taiga type which is not typical of Murmansk Region (Andreev 1975). An issue of conservation concern was raised when apatites had been discovered in the Turii Mys; ore mining would have completely destroyed this unique nature monument (Andreev 1975, Andreev et al. 1978). Luckily, this territory was promptly incorporated into the Kandalaksha Strict Nature Reserve in 1977 (Kryuchkov et al. 1988). To date, the Turii Mys is known to accommodate 26 species of vascular plants legally protected at the regional level and 6 species of vascular plants legally protected at the national level (Bardunov et al. 2008, Konstantinova et al. 2014).

Fellman's expeditions also visited the Lumbovka Bay on the north-eastern coast of the Kola Peninsula, where they discovered several rare plants. This territory was designated on herbarium labels and in publications as 'Sapadnivolok' or 'Sapadnij volok' and was referred to the Svyatoy Nos Cape because of the territorial proximity. However, in the travel diaries of Magnus Brenner (kept in the archive of the Society), who participated in the expeditions in 1863, this locality was noted as 'utskjutande udde vid Lumbofskij' (a prominent cape near Lumbovsky). Its correct Russian name was apparently 'Zapadnyi Navolok'; we traced it precisely at the mouth of the Zapadnaya River on the northwestern side of the Lumbovka Bay (Sennikov and Kozhin 2018).

The most remarkable finding at Lumbovka, new to Russian Lapland, was Astragalus oroboides $(=A$. norvegicus). Its nearest locality was known at the Varanger Fjord (Fellman 1831, Ledebour 1842) in Norway. In the same locality Fellman's expedition found Pleurogyne rotata (L.) Griseb. (= Lomatogonium rotatum (L.) Fr. ex Nyman) and 'Castilleja pallida (L.) Spreng.' (now C. lapponica Gand. ex Rebrist.). Both records were subsequently misplaced to the Svyatoy Nos (Hultén 1971, Konstantinova et al. 2014) and have not been recollected to date.

The Lumbovka Bay belongs to the least studied territories of Murmansk Region. Lately it has been visited by an expedition of the Polar-Alpine Botanical Garden-Institute, which discovered a number of rare plants and species-rich plant communities; on the basis of these discoveries, they proposed to protect the sea shore west of the Lumbovka Bay 
at the regional level. So far this proposal has not been implemented but the territory was listed among the Emerald

396 Network Areas of Special Conservation Interest in Russia (Sobolev and Belonovskaya 2011-2013). status. This publication reported four species that are currently treated as alien, i.e. Brassica campestris L., Polygala amarella Crantz, Vicia sepium L. and Veronica chamaedrys L. first checklist, Fellman (1831) listed 41 species on the basis of his own collections and observations; based on the collections of A. Schrenk, Ledebour (1841-1853) reported 2 more species. With the addition of 4 species in Fellman (1864a) and 7 species in Selin (1869), the flora of Russian Lapland included 54 non-native species of vascular plants in the beginning of the 1860s, which makes ca 11\% of the current total in Murmansk Region (Kozhin and Sennikov 2019).

\section{Confirmation of important previous records}

411

On the basis of travel reports (Fellman 1864a, Selin 1869) and their background data (herbarium specimens at H) it was possible to confirm historical records of some rare species in Russian Lapland which had previously been lacking any documentation.

In Russian Lapland, Asplenium crenatum (= Diplazium sibiricum) was reported for the first time from Kandalaksha (Nylander 1844, Ruprecht 1845) but the relevant herbarium collections have been unknown. Fellman's expedition has found this species in the vicinities of Ponoi Village and Soukelo, which currently belong to Murmansk Region and Karelian Republic, respectively.

Another remarkable species, Botrychium matricarioides Willd. (= Sceptridium multifidum (S.G.Gmel.) M.Nishida, syn. B. multifidum (S.G. Gmel.) Rupr.) was collected by Fellman at Kola. This species had been previously reported from the Kola Peninsula (at Kandalaksha) on the basis of material collected by F. Nylander (Ruprecht 1845), but no such specimens can be found at $\mathrm{H}$ or LE. 
424 herbarium specimens; so far, this record has received doubtful confirmation by specimens collected by V. Krohn in 1911

425 (at H). The first documented record of the species from the Kola Peninsula (Ponoi) was published by Fellman (1864a). Melandrium apetalum (L.) Fenzl (= Silene uralensis (Ruprecht) Bocquet) was first reported from 'Karelsgammen', an isthmus between the Vayda Bay and the Kiiskii Cape on the Rybachii Peninsula (Fellman 1831). Fellman (1864a) found it at the Kachkovka Bay. Neither record was supported by herbarium specimens.

\section{Completely erroneous records} uniflora (L.) Asch.), Raphanus raphanistrum L., Veronica officinalis L., which had not been confirmed by herbarium specimens. Fellman (1869a: 58) explained that the records of Raphanus raphanistrum and Veronica officinalis appeared because of an 'unexplainable'technical error and must therefore be rejected. Similarly, the record of Littorella uniflora was rejected, too (Hjelt 1923: 158). Such corrections are difficult to trace; this literature has been neglected in subsequent Russian works on the flora of Murmansk Region. discoveries. Peninsula (Sennikov and Kozhin 2018). Those results, pre-published in Fellman (1864a), not only increased the

\section{Discussion}

The information obtained by the Finnish botanical expeditions in 1861 was important to plan further trips to the Kola Peninsula, which were realised shortly thereafter in 1863 . It was also important to obtain funding to continue the exploration.

because that territory had been well explored by Selin in 1861 (Selin 1869). The exclusion of this territory allowed Fellman to rapidly continue eastwards and get concentrated on the Ponoi area, where he made many important botanical The main results of the expedition 1863 had been drafted by Fellman immediately on the way from the Kola knowledge on the flora of that territory and demonstrated its speciality within East Fennoscandia but also shaped the future plant geography of the Kola Peninsula. 

1864a, Selin 1869) contained important information on the flora of the Kola Peninsula. In terms of herbarium curation,

454 the reports included records of 87 species of vascular plants new to Lapponia rossica as defined in Herbarium Musei 455 Fennici (Nylander and Sælan 1859), and 9 species were completely new to the Botanical Museum of the University of 456 Helsinki. If all the published literature is taken into account, 43 species were actually new to Russian Lapland, which constituted an increase of ca. 9\% of the known plant diversity. With the reports, 504 species of vascular plants were known from Russian Lapland by the first half of the 1860s, of which 54 species were non-native. These numbers include not only present-day Murmansk Region but also the northern parts of the Republic of Karelia (largely the vicinities of Keret Village); for this reason, it is currently impossible to estimate the exact impact of the expeditions on the knowledge of the flora of Murmansk Region in particular, although many species first known from Keret were subsequently found in the southern part of Murmansk Region. Besides territorial novelties, Fellman (1864a) and Selin (1869) mentioned quite a number of more commonly distributed plants; these mentions were really important for the future synopsis of the flora of this poorly known territory. These persons, having travelled separately, differently understood the task of their studies. Fellman was more focused on native, rare and characteristic species, whereas Selin also included alien plants which he spotted in the nearest proximity of villages. The value of the latter information was not understood in Fellman's times and such reports were not appreciated by the Society (Sennikov and Kozhin 2018), but nowadays those early records of non-native plants have a special value in understanding times, pathways and dynamics of human-assisted plant immigration to the Kola Peninsula (Kozhin and Sennikov 2019).

For the first time in studies on the Kola Peninsula, Fellman (1864a) clearly held a synthetic view of the flora. He 472 described a phytogeographical features of the territory and traced limits for floristic districts which have been 473 established later largely on the basis of his results. He also described some botanically unusual territories which later 474 became legally protected, and provided the first botanical data from those territories. Further on, the floristic records published in Fellman (1864a) and Selin (1869) were taken into account in the 477 synopsis of the flora of East Fennoscandia (Hjelt 1888, 1892, 1895, 1902, 1906, 1911, 1919, 1923, 1926). Although 478 these works belong to major publications on the flora of East Fennoscandia and their copies have been widely and 479 timely distributed (also to main Russian botanical libraries: e.g. Herder 1886), Fellman's and Selin's records were omitted from major Russian treatments of the flora of Murmansk Region (Gorodkov 1953-1954, Pojarkova 1956-1966, 
481 Ramenskaya 1983). Only due to our inventories this information has been included into the latest version of the Red

482 Data Book of Murmansk Region (Kostantinova et al. 2014).

483

484

485

486

\section{Conclusions}

Express publications in small formats (letters, travel reports) that were common means of rapid communication of important information (most significant field records and new taxa) in the $19^{\text {th }}$ century, may have been overlooked or mistreated as insignificant by botanists of the $20^{\text {th }}$ century. To avoid losses of information in comprehensive databases of the $21^{\text {th }}$ century, also minor publications should be screened and recorded.

The information delivered in field reports of the Finnish botanical expeditions to the Kola Peninsula (Fellman 1864a, Selin 1869) included many first and early records of rare native plants, of which several are currently under legal protection (Konstantinova et al. 2014). Their records of alien plants help uncover time and pathways of introduction of the non-native flora in the Arctic and Subarctic territories, which is currently in focus of active exploration because of potential danger to the native flora and human economy and well-being (Wasowicz et al. 2019). For the first time in East Lapland, Fellman (1864a) presented a phytogeographical description of the territory and determined some key limits of plant distributions; this work laid foundation for the complete phytogeographical scheme (Fellman 1869) that became the basis for further studies on the flora and vegetation of the territory for the following 100 years (Ramenskaya 1983). Key areas visited and described as such by the expeditions have been subsequently protected (Borovichev et al. 2018). The reports (Fellman 1864a, Selin 1869) not only have a high historical value as pioneer studies on the flora and vegetation of the Kola Peninsula but also remain a source of actual information on occurrences of legally protected plants because of the current lack of information on the population status of several species and little knowledge available on some remote and little-explored parts of the territory. Our critical examination of the reports contributes to the history of botanical exploration of the Kola Peninsula (Wallgren 1996, Sennikov and Kozhin 2018) and to the current botanical research, which aims to construct a comprehensive database in order to produce a precise phytogeography, to provide background for plant protection, and to develop informed decisions on plant invasions in Murmansk region of Russia.

\section{References}


Ahti, T. et al. 1968. Vegetation zones and their sections in northernmost Europe. — Ann. Bot. Fenn. 5: 169-211.

Alexandrova, V.D. 1977. Geobotanicheskoe raionirovanie Arktiki i Antarktiki [Geobotanical subdivision of the Arctic and the Antarctic]. — Science Publishers. [In Russian.]

Andersson, N.J. 1846. Conspectus vegetationis Lapponicae. — Wahlström \& C.

Andreev, G.N. 1975. Turii mys kak pamyatnik prirody [Turii cape as a natural monument]. — In: Bianki, V.V. and Filippova, L.N. (eds.), Estestvennaya sreda i biologicheskie resursy Krainego Severa [Natural environment and biological resources of the Far North]. Geographical Society of the USSR, pp. 127-130. [In Russian.]

Andreev, G.N. et al. 1978. Unikal'nost' Tur'ego mysa s botanicheskoi tochki zreniya [The uniqueness of Turii Cape from a botanical point of view]. — In: Luk'yanova, L.M. (ed.), Botanicheskie issledovaniya za Polyarnym krugom [Botanical research at the Arctic Circle]. Kola branch of the USSR Academy of Sciences, pp. 14-23. [In Russian.]

Anonymous 1938. Suomen luonnontieteellisen alueen paikannimiluettelo. — Ann. Entomol. Fenn. 4: 128-144.

Bardunov, L.V. et al. (eds.) 2008. Krasnaya kniga Rossiiskoi Federatsii. Rasteniya [Red Data Book of Russian Federation. Plants]. — KMK Scientific Press. [In Russian.]

Belkina, O.A. et al. 2018. Briologicheskoe obosnovanie sozdaniya Orlov-Ponoiskogo zakaznika (Kol'skii poluostrov) [Bryological rationale for establishment of the Orlov-Ponoi nature sanctuary (Kola Peninsula)]. — Trudy Karel'skogo Nauchnogo Centra RAN 8: 61-76. [In Russian with English summary.]

Bomansson, J.O. and Brotherus, V.F. 1894. Herbarium Musei Fennici (ed. 2), vol. 2. — Finska Litteratur-Sällskapet. Borovichev, E.A. et al. 2018. Protected areas network in the Murmansk Region: yesterday, today, and tomorrow. Arktika i Sever 32: 107-120. [In Russian with English summary.]

Fellman, J. 1831. Index plantarum phanerogamarum in territorio Kolaënsi lectarum. - Bull. Soc. Imp. Naturalistes Moscou 3: 299-328.

Fellman, N.I. 1864a. Lettre de M. N.-I. Fellman à M. William Nylander, sur un voyage botanique dans la Laponie orientale. - Bull. Soc. Bot. France 10: 495-502.

Fellman, N.I. 1864b. Botanische Reise im russischen Lappland. — Flora 47: 381-384.

Fellman, N.I. 1865. Botanical excursion to eastern Lapland. — Quart. J. Sci. 2: 659-661.

Fellman, N.I. 1869. Plantae vasculares in Lapponia Orientali sponte nascentes. — Not. Sällsk. Fauna Fl. Fenn. Förh. 8: I-LXX + 1-99. 
Filippova, L.N. 1988. Helianthemum arcticum (Grosser) Janch. — In: Takhtajan, A.L. (ed.), Krasnaya kniga RSFSR. Rasteniya [Red Data Book of RSFSR. Plants]. Agropromizdat, pp. 140. [In Russian]

Gorodkov, B.N. (ed.) 1953-1954. Flora Murmanskoi oblasti [Flora of Murmansk Region], vols. 1-2. — Vol. 1 (1953). Vol. 2 (1954). — Academy of Sciences of the USSR. [In Russian]

Grosser, W. 1903. Cistaceae Juss. — In: Engler, A. (ed.), Das Pflanzenreich, IV.193 (= Heft 14). Engelmann, pp. 1-161.

Hämet-Ahti, L. 1987. Mountain birch and mountain birch woodland in NW Europe. — Phytocoenologia 15: 449-453.

Herder, F. von 1886. Catalogus systematicus bibliothecae Horti Imperialis botanici Petropolitani. Editio nova. — Academia Caesarea Scientiarum, Saint-Petersburg.

Hjelt, H. 1888. Conspectus Florae Fennicae. Pars I. Pteridophyta et Gymnospermae. — Acta Soc. Fauna Fl. Fenn. 5(1): $1-107$.

Hjelt, H. 1892. Conspectus Florae Fennicae. Pars II. Monocotyledoneae: Liliaceae-Carices homostachyae. — Acta Soc. Fauna Fl. Fenn. 5(1): 109-258.

Hjelt, H. 1895. Conspectus Florae Fennicae. Pars III. Monocotyledoneae: Carices distigmaticae-Najadaceae. — Acta Soc. Fauna Fl. Fenn. 5(1): 259-562.

Hjelt, H. 1902. Conspectus Florae Fennicae. Vol. II. Dicotyledoneae. Pars I. Amentaceae-Polygonaceae. — Acta Soc. Fauna Fl. Fenn. 21(1): 1-261.

Hjelt, H. 1906. Conspectus Florae Fennicae. Vol. III. Dicotyledoneae: Pars II. Caryophyllaceae-Resedaceae. — Acta Soc. Fauna Fl. Fenn. 30(1): 1-410.

Hjelt, H. 1911. Conspectus Florae Fennicae. Vol. IV. Dicotyledoneae: Pars III. Violaceae-Elaeagnaceae. — Acta Soc. Fauna Fl. Fenn. 35(1): 1-411.

Hjelt, H. 1919. Conspectus Florae Fennicae. Vol. V. Dicotyledoneae: Pars IV. Rosaceae-Solanaceae. - Acta Soc. Fauna Fl. Fenn. 41(1): 1-502.

Hjelt, H. 1923. Conspectus Florae Fennicae. Vol. VI. Dicotyledoneae: Pars V. Scrophulariaceae-Dipsacaceae. — Acta Soc. Fauna Fl. Fenn. 51(1): 1-450.

Hjelt, H. 1926. Conspectus Florae Fennicae. Vol. VII. Dicotyledoneae: Pars VI. Compositae. — Acta Soc. Fauna Fl. Fenn. 54(1): 1-397.

Hultén, E. 1971. Atlas över växternas utbredning i Norden. 2:a uppl. — Generalstabens litografiska anstalts förlag. Janchen, E. 1909. Die Cistaceen Österreich-Ungarns. — Mitt. Naturwiss. Vereins Univ. Wien 7: 1-124. 
Karsten, P.A. 1866. Enumeratio fungorum et mycomycetum in Lapponia orientali æstate 1861 lectorum. — Not. Sällsk. Fauna Fl. Fenn. Förh. 8: 193-224.

Konstantinova, N.A. et al. (eds.) 2014. Krasnaya kniga Murmanskoi oblasti [Red Data Book of the Murmansk Region], ed. 2. - Government of the Murmansk Region \& Ministry of Nature Resources and Environment of the Murmansk Region. [In Russian.]

Kostina, V.A. 2008. Helianthemum arcticum (Grosser) Janch. — In: Bardunov, L.V. et al. (eds.), Krasnaya kniga Rossiiskoi Federatsii. Rasteniya [Red Data Book of Russian Federation. Plants]. KMK Scientific Press, pp. 178-179. [In Russian.]

Kozhin, M.N. and Sennikov, A.N. 2019. Antropogennye izmeneniya vo flore Russkoi Laplandii [Anthropogenic changes in the flora of Russian Lapland]. — In: Geltman, D.V. et al. (eds.), Innovations and traditions in present-day botany: Abstracts of the National Conference with international participation, dedicated to the $150^{\text {th }}$ anniversary of V. L. Komarov, Saint-Petrsburg, 21-25 October 2019. [Komarov Memorial Lectures 48] Komarov Botanical Institute, p. 51. [In Russian.]

Kozhin, M.N. et al. 2018. Dopolneniya i utochneniya po rasprostraneniyu redkikh i okhranyaemykh vidov sosudistykh rastenii Ponoiskoi Laplandii (Murmanskaya oblast') [Additions and corrections to the records of rare and redlisted vascular plants in Lapponia Ponojensis, Murmansk Region]. — Trudy Karel'skogo Nauchnogo Centra RAN 1: 33-50. [In Russian with English summary.]

Kryuchkov, V.V. et al. 1988. Krasnaya kniga ekosistem Kol'skogo Severa [Red Book of ecosystems of the Kola North]. — Kola branch of the USSR Academy of Sciences. [In Russian.]

Kurtto, A. et al. (eds.) 2013. Atlas Florae Europaeae. Distribution of Vascular Plants in Europe, vol. 16. — The Committee for Mapping the Flora of Europe \& Societas Biologica Fennica Vanamo.

Kurtto, A. et al. 2019. Checklist of the vascular plants of Finland. — Finnish Museum of Natural History.

Ledebour, C.F. von 1841-1853. Flora Rossica, vols. 1-4. — Vol. 1 (1841-1843). Vol. 2 (1843-1846). Vol. 3 (18471851). Vol. 4 (1852-1853). — E. Schweizerbart.

Linnaeus, C. 1737. Flora Lapponica exhibens plantas per Lapponiam crescentes, secundum systema sexuale collectas in itinere impensis Soc. Reg. Litter. et Scient. Sveciae a. 1732 instituto. Additis synonymis, \& locis natalibus omnium, descriptionibus et figuris rariorum, viribus medicatis \& oeconomicis plurimarum. - Apud Salomonem Schouten.

Nylander, F. 1843. Spicilegium plantarum Fennicarum. Centuria 1. — Frenckell. 
Nylander, F. 1844. Spicilegium plantarum Fennicarum. Centuria 2. — Frenckell.

Nylander, F. 1846. Spicilegium plantarum Fennicarum. Centuria 3. — Frenckell.

Nylander, W. 1852. Collectanea in Floram Karelicam. — Not. Sällsk. Fauna Fl. Fenn. Förh. 2: 109-181.

Nylander, W. 1866. Lichenes Lapponiae orientalis. — Not. Sällsk. Fauna Fl. Fenn. Förh. 8: 101-192.

Nylander, W. and Sælan, T. 1859. Herbarium Musei Fennici. — Finska Litteratur-Sällskapet.

Pojarkova, A.I. (ed.) 1956-1966. Flora Murmanskoi oblasti [Flora of Murmansk Region, vols. 3-5]. — Vol. 3 (1956). Vol. 4 (1959).Vol. 5 (1966). — Academy of Sciences of the USSR. [In Russian.]

Ramenskaya, M.L. 1983. Analiz flory Murmanskoi oblasti i Karelii [Analysis of the flora of the Murmansk region and Karelia]. — Science Press. [In Russian.]

Ramenskaya, M.L. and Andreeva, V.N. 1982. Opredelitel' vysshikh rastenii Murmanskoi oblasti i Karelii [Guide to the higher plants of Murmansk Region and Karelia]. — Science Press. [In Russian.]

Ruprecht, F.J. 1845. Distributio Cryptogamarum Vascularium in Imperio Rossico. — Beitr. Pflanzenk. Russ. Reiches 3 : $1-56$.

Safronova, I.N. et al. 1999. Zony i tipy poyasnosti rastitel'nosti Rossii i sopredel'nykh territorii [Zones and altitudinal zonality types of the vegetation of Russia and adjacent territories]. — Faculty of Geography of Moscow State University \& Komarov Botanical Institute. [In Russian and partly in English.]

Schljakov, R.N. 1966. Hieracium L. — In: Pojarkova, A.I. (ed.), Flora Murmanskoi oblasti [Flora of Murmansk Region] 5: 268-424, 427-460. Science Publishers. [In Russian.]

Saelan, T. et al. 1889. Herbarium Musei Fennici (ed. 2), vol. 1. — J. Simelius.

Selin, G. 1869. Bref till professor William Nylander. — Not. Sällsk. Fauna Fl. Fenn. Förh. 8: LXVII-LXX.

Sennikov, A.N. and Kozhin, M.N. 2018. The history of the Finnish botanical exploration of Russian Lapland in 1861 and 1863. - Memoranda Soc. Fauna Fl. Fenn. 94: 1-35.

Sobolev, N.A. and Belonovskaya, E.A. 2011-2013. Izumrudnaya kniga Rossiiskoi Federatsii. Chast' 1 [Emerald Book of Russian Federation. Part 1]. — Institute of Geography of the RAS. [In Russian.]

Tzvelev, N.N. 1996. Cistaceae Juss. — In: Tzvelev, N.N. (ed.), Flora Vostochnoi Evropy [Flora of East Europe], vol. 9. — World and Family Publishers, pp. 206-216. [In Russian.]

Tzvelev, N.N. 2004. Betulaceae S. F. Gray. — In: Tzvelev, N.N. (ed.), Flora Vostochnoi Evropy [Flora of East Europe], vol. 11. KMK Scientific Press, pp. 63-90. [In Russian.]

Väre, H. 2011. Jacob Fellman - the botanising priest. — Memoranda Soc. Fauna Fl. Fenn. 87: 1-20. 
624 Vekhov, V.N. 1992. Zostera morskaya (Zostera marina L.) Belogo morya [Common eelgrass (Zostera marina L.) of the 625 White Sea]. — Moscow State University Press. [In Russian.]

626 Volkova, P.A. et al. 2016. Phylogeography of the European rock rose Helianthemum nummularium s.l. (Cistaceae):

627 Western richness and eastern poverty. — Pl. Syst. Evol. 302: 781-794.

628 Wahlenberg, G. 1812. Flora Lapponica exhibens plantas geographice et botanice consideratas, in Lapponiis suecicis 629 scilicet umensi, pitensi, lulensi, tornensi et kemensi nec non Lapponiis norvegicis scilicet Nordlandia et $630 \quad$ Finmarkia utraque indigenas, et itineribus annorum 1800, 1802, 1807 et 1810 denuo investigatas. — In Taberna 631 libraria Scholae realis.

632 Wallgren, H. 1996. Societas pro Fauna et Flora Fennica 1821-1996: A short outline. — Memoranda Soc. Fauna Fl. $633 \quad$ Fenn. 72: 81-98.

634 Wasowicz, P. et al. 2019. Non-native vascular flora of the Arctic: Taxonomic richness, distribution and pathways. 635 Ambio 49: 693-703.

636 
637 Figure 1. Collection locations of Finnish botanical expeditions to Russian Lapland in 1861 and 1863 (Murmansk Region 638 and northern Karelia), showing localities that provide the background for Fellman (1864a) and Selin (1869). Adapted 639 from Sennikov and Kozhin (2018). Phytogeographical limits follow Anonymous (1938).

640

641 Figure 2. Progress in floristic studies in Russian Lapland as traced from major early published sources (taxonomic 642 richness recorded, including species and those varieties that were subsequently elevated to the species level).

643

644 Figure 3. Biogeographical provinces of Russian Lapland based on (left) Nylander and Sælan (1859) and (right)

645 Anonymous (1938). Abbreviations: Kk — Karelia keretina, Ks — Karelia kuusamoenis, Kr — Karelia rossica, L —

646 Lapponia fennica, Lim — Lapponia Imandrae, Lm — Lapponia murmanica, Lp — Lapponia ponojensis, Lps —

647 Lapponia petsamoensis, $\mathrm{Lr}$ — Lapponia rossica, Lt — Lapponia tulomensis, Lv — Lapponia Varsugae, O —

648 Ostrobottnia borealis; Poc — Karelia pomorica occidentalis, Por — Karelia pomorica orientalis. 